\title{
Mass spectrometry study of plant steroid glycosides and their interactions with biomolecules
}

\author{
V. V. Pilipenko, L. F. Sukhodub \\ Institute of Applied Physics, National Academy of Sciences of Ukraine \\ Petropavlivs'ka st., 58, Sumy, 40030, Ukraine \\ E-mail: vie@rbcmail.ru
}

\begin{abstract}
A number of plant steroid glycosides ( SGs) and genins have been investigated by ${ }^{252} \mathrm{Cf}$ plasma desorption mass spectrometry $\left({ }^{252} C f\right.$ TOF-PDMS). PDMS was also applied for comparative studies of the interactions of SGs and their genins with basic amino acids, nucleosides and AMP. SGs can interact with these biomolecules to form heteroclusters of the types ISG+biomolecule $+\mathrm{HI}^{+}$and I $\mathrm{SG}+$ biomolecule $+\mathrm{K} \Gamma^{+}$, the affinity of SGs for biomolecules depends on the structures of the $S G$ carbohydrate chain and the $S G$ aglycone, and the biomolecule nature.
\end{abstract}

Steroid glycosides (SGs) are glycosylated secondary metabolites that commonly occur in the higher plants: more than 500 species belonging to nearly 80 different plant families can synthesise saponins $[1-3]$. The SGs basic structure is a hydrophobic steroid ring (sapogenin or aglycone) of spirostan or furostan series attached to a hydrophilic chain of deferent sugar moieties. A sugar may be linked to the aglycone at one or two glycosylation sites, giving either monodesmosidic or bidesmosidic SGs, respectively $[1-3]$. SGs represent one of the most promising classes of pharmacological substances used to treat more than 100 diseases $[1-3]$. Most biological activities of SGs are ascribed to their interaction with biomembranes and separate biomolecules, e. g. with cholesterol and proteins $[1-3]$. However, the mechanism underlying the SGs biochemical activity is not fully understood and requires further investigations.

SGs and genins of spirostan and furostan series have been investigated by ${ }^{252} \mathrm{Cf}$ plasma desorption mass spectrometry ${ }^{252} \mathrm{Cf}$ TOF-PDMS). The experimental part connected with the procedure of extraction, purification and sample preparation of SGs and genins for PDMS investigation as well as principal schemes of PDMS method are described in [4-6]. Firstly we recorded the mass spectra for well-characterized aglycones and SGs. They were studied with

(C) V. Y. PLLPENKO, L. F. SUKHODUB, 2002 the IR and NMR methods before the PDMS investigation, also complete acid and enzymatic hydrolysis and methylation were performed. [7-9]. These investigations and detailed analysis of mass spectra permitted to make a conclusion about the main features of the PDMS spectra of SGs measured and served as a basis for mass spectrometry studies of genin and SG samples whose molecular mass and structure had been determined initially, but required further verification and confirmation, and to create a mass spectral database. The database allows 1) distinguishing between SGs and genins in the pure samples and crude plant extracts, 2) determination of molecular mass of SGs and genins, as well as 3) determination of aglycone (genin) and carbohydrate chain composition and structure of SGs.

PDMS has also been applied to comparative studies of the interactions of some SGs: neotigogenin monoside (NM), neotigogenin bioside (NB), neotigogenin trioside (NT), petunioside $\mathrm{D}$ (PD) and their genins of the spirostan series neotigogenin and gitogenin with 20 basic amino acids, nucleosides (Ado, Cyd, Guo, Thd, and Urd) and adenosine 5 -monophosphate (AMP). The chemical structures of neotigogenin, NM, NB, NT, gitogenin, and PD were shown in our previous articles [4-6]. The mass spectra of the SGs (NM, NB, PD) and genins were also shown and described in details in the previous articles [4-6]. The mass spectra of model mixtures 
PLLIPENKO V. V., SUKHODUB L. F.

PDMS data on steroid glycoside-amino acid interaction. Instrumental error in the $\mathrm{m} / \mathrm{z}$ range 500 to $1500 u$ is $\pm 2 u$. The dash indicates that there is no steroid glycoside-amino acid interaction

\begin{tabular}{|c|c|c|c|c|c|c|}
\hline \multirow{3}{*}{ Amino actd } & \multicolumn{6}{|c|}{ Sterold glycoside } \\
\hline & \multicolumn{2}{|c|}{ NB } & \multicolumn{2}{|c|}{ NT } & \multicolumn{2}{|c|}{ PD } \\
\hline & {$[\mathrm{NB}+\mathrm{M}+\mathrm{H}]^{+}$} & {$\left[\mathrm{NB}+\mathrm{M}+\mathrm{K}^{+}\right.$} & {$[\mathrm{NT}+\mathrm{M}+\mathrm{H}]^{+}$} & {$[N T+M+K]+$} & $\{\mathrm{PD}+\mathrm{M}+\mathrm{H}\}^{+}$ & {$[\mathrm{PD}+\mathrm{M}+\mathrm{K}]+$} \\
\hline Alanine & $831^{* * *}$ & $870^{* *}$ & $993^{* * *}$ & - & $846^{* * *}$ & - \\
\hline Arginine & - & - & - & - & - & - \\
\hline Asparagine & $873^{* * *}$ & $910^{* *}$ & $1036^{* * *}$ & $1074^{*}$ & $891^{* * *}$ & - \\
\hline Aspartic acid & $875^{* *}$ & $913^{* * *}$ & - & $1074^{* * *}$ & $892^{* * *}$ & - \\
\hline Cystein & $862^{* *}$ & $901 * *$ & $1024^{* * *}$ & $1063^{* *}$ & - & - \\
\hline Glutamic acid & $889^{* * *}$ & $928^{* * *}$ & $1051^{* * *}$ & - & $909^{*}$ & - \\
\hline Glutamine & {$[888]^{-* *}$} & $927^{* * *}$ & $1050^{* * *}$ & $1089^{* * *}$ & $904^{* *}$ & - \\
\hline Glycine & $818^{* * *}$ & - & $978 * * *$ & $1017^{* * *}$ & $832^{* * *}$ & - \\
\hline Histidine & - & - & - & - & - & - \\
\hline Leucine & $873^{* *}$ & $911^{* *}$ & $1033^{* *}$ & - & $890^{* *}$ & - \\
\hline Isoleucine & $873^{* *}$ & $911^{* *}$ & $1033^{* *}$ & - & $890^{* *}$ & - \\
\hline Lysine & - & - & - & - & - & - \\
\hline Methionine & - & - & - & - & - & - \\
\hline 3-hydroxyproline & $874^{* *}$ & $913^{* * *}$ & $1036^{* * *}$ & $1073^{*}$ & $891^{* *}$ & - \\
\hline Phenylalanine & $907^{*}$ & $946^{* *}$ & $1067^{* *}$ & $1106 * *$ & $924^{* * *}$ & $961 * *$ \\
\hline Serine & $849^{* * *}$ & $885^{* *}$ & $1006^{* * *}$ & $1044^{* * *}$ & $862^{* * *}$ & $902^{*}$ \\
\hline Threonine & $860^{* *}$ & $899^{* *}$ & $1022^{* *}$ & $1058^{*}$ & $877^{* * *}$ & - \\
\hline Tryptophan & - & - & - & - & $961^{*}$ & $1001^{*}$ \\
\hline Tyrosine & $924^{*}$ & - & $1084^{*}$ & - & $939^{* *}$ & - \\
\hline Valine & $859^{* * *}$ & $898^{* * *}$ & $1020^{* * * *}$ & - & $874^{* * *}$ & - \\
\hline
\end{tabular}

${ }^{*}$ Weak interaction; ${ }^{* *}$ average interaction; ${ }^{* * *}$ strong interaction.

of SG with certain biomolecule show that SGs can form heteroclusters with amino acids, nucleosides or AMP. The mass spectra indicate also that only SGs with carbohydrate chain containing more than one sugar can form heteroclusters of the types [SG ++ biomolecule $+\mathrm{Na}]^{+}, \quad\left[\mathrm{SG}+\right.$ biomolecule $+\mathrm{K}^{+}$and $[\mathrm{SG}+\text { biomolecule }+\mathrm{H}]^{+}$. The intensity of peaks of heterocluster ions depends on structure of aglycone and amount of sugars moiety in carbohydrate chaine of SG.

For instance, the most striking results of analyses of SG-amino acid mixtures listed in Table, demonstrate that SGs with a larger carbohydrate com- ponent (NT) and extra hydroxyl group (PD) in the aglycone have a greater affinity to amino acids, favoring polar negatively-charged at physiological $\mathrm{pH}$ and polar uncharged amino acids.

The same results we obtained in the case of model mixtures of SGs (NM, NB and PD) and genins (neotigogenin and gitogenin) with nucleosides and AMP [6]. The most intense peaks of these heteroclusters in comparison with molecular ions were observed in case of mixtures SGs with Urd. The mass spectra of model mixtures of neotigogenin, gitogenin or NM with nucleosides and AMP show only peaks of individual mixture components. 
These results can be used for the explanation of some aspects of SG pharmacological activity and its ability to interact with the native biopolymers (proteins, DNA or RNA) or with their components (amino acids, nucleosides or nucleotides). For example, the complexes formed by SGs with glycoplastic (Ala, Gly, Glu, His, Pro, Ser, Thr) and ketoplastic (Leu, Phe, Tyr) amino acids may be the cause of the SG effect on gluconeogenesis and coenzyme $A$ synthesis in a cell, respectively $[10]$.

\section{В. В. Пилипенко, Л. Ф. Суходуб}

Мас-спектрометричне вивчення рослинних стероїдних глікозидів та іхкьої взаємодії з біомолекулами

Резюме

Досліджували молекулярну масу та структуру рослинних препаратів стероїднх глікозидів (СГ) та генінів за допомогою методу часопролітної плазменно-десорбційної мас-спектрометрї 3 іонізацікю уламками поділу ${ }^{252} \mathrm{Cf}$ (ПДМС). ПДМС також застосовано у дослідженнях взаємодї ряду препаратів СГ та генінів з біомолекулами амінокислотами, нуклеозидами, аденозин-S'-монофосфатом. Дані мас-спектрів показали, цо СГ здатні взасмодіяти з вказаними біомолекулами утьоренням нековалентно зв'язаних асоціатів по типу $/ \mathrm{Cr}+$ + біомолекула $+\mathrm{HJ} / \mathrm{Cr}+$ біомолекула $+\mathrm{K} J^{+}$. Iнтенсивність цієї взаємодї залежить від хімінної структури СI та біомолекули.

\section{B. В. Пинипенко, Суходуб Л. Ф.}

Масс-спектрометрическое изучение растительных стероидных гликозидов и их взаимодействия с биомолекулами

Резюме

Исследованы молекулярная масса и структура растительных препаратов стероидных гликозидов (CГ) и генинов с помощью метода времяпролетной плазменно-десорбционияй масс-спектрометрии с ионизачией осколками деления ${ }^{252} \mathrm{Cf}$ (ПДМС). ПІДМС такхе применена для изуиения взаимодейстөия ряда препаратов СГ и генинов с биомолекулами: аминокислотами, нуклеозидами, аденозин-5'-монофосфатом. Даннье масс-спек- тров указывают на способность этих СГ взаимодействовать с биомолекулами с образованием нековалентно связанньх ассоциатов по типу $/ C \Gamma+$ биомолекула $+\mathrm{H}]^{+}[\mathrm{C} \Gamma+$ биомолекула $+\mathrm{K}]^{+}$. Интенсивность данного взаимодействия зависит от химической структуры СГ и биомолекуль.

\section{REFERENCE}

1. Kintia P. K, Lazuryevskiy G, V., Balashova N. N., Balashova I. T., Suruzhiu A. I., Lyakh V. A. Structure and biological activity of steroidal glycosides of the spirostan and furostan series.-Kishinau: Shtiintsa, 1987.--240 p.

2. Hostettmann $\mathcal{K}$, Marston A. Saponins.-Cambridg: Cambridge Univ. press, $1995 .-450 \mathrm{p}$.

3. Fieser $L$., Fieser $M$. Steroids.-M.: Mir, 1964.-982 p.

4. Pilipenko V. V., Sukhodub L. F., Aksyonov S. A., Kalinkevich A. N., Kintia P. K. ${ }^{252} \mathrm{Cf}$ PDMS study of interactions of steroid glycosides with amino acids // Rapid Commun. Mass Spectrom. $-2000 .-\mathrm{N} 14 .-\mathrm{P} .819-823$.

5. Pilipenko V. V., Aksyonov S. A., Kalinkevich A. N., Sukhodub $L$. $F$. Interactions between steroid glycosides and amino acids: investigations by plasma desorption mass spectrometry // Biopolimery i kletka.-2000.-16, N 3.-P. 212-219.

6. Pilipenko V. V., Aksyonov S. A., Kalinkevich A. N., Sukhadub $L$. $F$. PDMS investigations of steroid glycosides interactions with nucleosides // Vis. Kharkov univer. $-1999 .-434$, N 3.P. $56-62$.

7. Kintia $P$. $K$. Chemistry and biological activity of steroidal saponins from Moldavian plants. Saponins used in traditional and modern medicine // Adv. Exp. Med. and Biol. $-1996 .-$ 404. -P. 309-334.

8. Spinu K., Vorozhbit V., Grushko T., Kintia P., Skofertsa P., Bolova $V$. Antiviral activity of Tomatoside from Lycopersicon esculentum Mill. Saponins used in traditional and modern medicine $/ /$ Adv. Exp. Med. And Biol.-1996.-404.P. 505-511.

9. Shvets S. A., Kintia P. K., Naibi M. A. Steroidal glycosides from Petunia hybrida L. Seeds and their biological activity. Saponins used in traditional and modern medicine $/ /$ Adv. Exp. Med. and Biol.-1996--404.-P. 251-263.

10. Donalt V., Judith $G$. V., Charlotte $W$. Pratt fundamentals of biochemistry.-New York: John Wiley and Sons. Inc., 1999.P. 980 .

УДК 577.3

Надійшла до редакції 03.10.01 